\title{
Methods to Characterize Fly Ash Quality in the Field
}

\author{
Triwulan $^{\#}$, Khorin Agus Priadana ${ }^{\#}$, Januarti Jaya Ekaputri ${ }^{\#}$ \\ ${ }^{\#}$ Civil Engineering Department, Faculty of Civil Engineering and Planning, Institut Teknologi Sepuluh Nopember (ITS), Surabaya, Indonesia \\ E-mail: triwulan_marwan@yahoo.com
}

\begin{abstract}
Fly ash is applied widely in concrete. Therefore, the quality of fly ash plays a critical role in altering the compressive strength of concrete. As the fact, it is necessary to provide better insight on the characterization of fly ash based on their correlation index against the strength. This is regarded as the prior studies were merely focused on the relationship of fly ash percentage and compressive strength due to high demand and time-consuming. On the other hand, this paper offers more advanced analysis on the utilization of several methods to determine the effect of different fly ashes on the quality of mortar. In this study, 12 types of fly ash and six methods were involved. The differences between the methods consisted of how the samples were prepared and cured. In the mixture, $20 \%$ of fly ash and $80 \%$ of OPC (Ordinary Portland Cement) were used as a binder. The specimens were cured in two different methods (normal curing and steam curing). After 28-day of curing, specimens were tested under compression load to obtain the strength. The test results indicated that the method, where the fly ash was sieved in the preparation phase and was cured at a high temperature increased gradually, was found to be the fastest to analyze.
\end{abstract}

Keywords - quality of fly ash; binder; steam curing; characterization

\section{INTRODUCTION}

The quality of fly ash depends on the quality of coal and also the method of calcination process [1]. There are many types of coals in the field, resulting in the extent variations of the quality of fly ash. Fly ash as a binder of concrete affects the performance of concrete or mortar. Many readymix concrete industries use fly ashes as its mixed material. Therefore, it is necessary to determine the correlation of fly ash quality to the compressive strength of mortar. It is not simple to determine this correlation; it depends on the quality of fly ash as mineral content, oxide content, and phases amorphous of fly ash. Since of limitations of existing equipment, it is not easy and not inexpensive to determine the content of fly ash. The condition causes that to determine the correlation between the quality of fly ash and its influence on the compressive strength of the mortar is not simple, expensive and takes a long time.

Therefore, this study was used several approaches to determine the effect of different quality fly ash on the compressive strength of mortar. The research was used 12 types of fly ashes from several diverse sources. Specimens were in the form of paste and mortar, the mixture of binders was formed by OPC and fly ash by the weight ratio $20 \%$ of fly ash and $80 \%$ of OPC. To determine the correlation of fly ash content to the compressive strength of the mortar or paste, 6 different methods were used in this study. Each of methods differed in the preparation procedure and curing process. Test results that provide the fastest response to the compressive strength that was chosen as the reference.

\section{MATERIAL AND METHOD}

\section{A. Materials}

The basic material of this research is fly ash.

1) Oxide Content of Fly Ash: The oxide content of fly ash used in this present work is presented in Table 1. The abbreviations used in the columns code relate to the origin of fly ash were taken. From Table 1, it is shown that the fly ash utilized in the experiment generally satisfy the requirements of fly ash type F according to ASTM C-618 [2], with the number of $(\mathrm{SiO} 2+\mathrm{Al} 2 \mathrm{O} 3+\mathrm{Fe} 2 \mathrm{O} 3)$ is found to be greater than $70 \%$. The numbers listed in the index column are indicated by the percentage of the amount chemical oxide content of the fly ash. Number 1 indicates that the percentage amount of $(\mathrm{SiO} 2+\mathrm{Al} 2 \mathrm{O} 3+\mathrm{Fe} 2 \mathrm{O} 3)$ is ranged from 90-100. Number 0.9 indicates that the percentage amount of $(\mathrm{SiO} 2+\mathrm{Al} 2 \mathrm{O} 3+\mathrm{Fe} 2 \mathrm{O} 3)$ is ranged from 80-90. Number 0.8 indicates that the percentage amount of $(\mathrm{SiO} 2+$ $\mathrm{Al} 2 \mathrm{O} 3+\mathrm{Fe} 2 \mathrm{O} 3$ ) is ranged from 70-80, and the number 0.7 indicates that the percentage amount of $(\mathrm{SiO} 2+\mathrm{A} 12 \mathrm{O} 3+$ $\mathrm{Fe} 2 \mathrm{O} 3$ ) is ranged from 60-70. 
TABLE I

OXIDE CONTENT OF FLy ASH

\begin{tabular}{|c|c|c|c|c|c|c|c|c|}
\hline CODE & $\mathbf{A l}_{\mathbf{2}} \mathbf{O}_{\mathbf{3}}$ & $\mathbf{F e}_{\mathbf{2}} \mathbf{O}_{\mathbf{3}}$ & $\mathbf{S i O}_{\mathbf{2}}$ & $\mathbf{S O}_{\mathbf{3}}$ & $\mathbf{S i O}_{\mathbf{2}}+\mathbf{A l}_{\mathbf{2}} \mathbf{O}_{\mathbf{3}}+\mathbf{F e}_{\mathbf{2}} \mathbf{O}_{\mathbf{3}}$ & $\mathbf{C a O}$ & \multicolumn{2}{|c|}{ ASTM } \\
\hline PJB 1 & 22 & 5.2 & 51.91 & 0 & 79.11 & 13.1 & $\mathrm{~F}$ & 0.8 \\
\hline PJB 2 & 18 & 4.6 & 53.79 & 0 & 76.39 & 15.6 & $\mathrm{~F}$ & 0.8 \\
\hline IMO & 15 & 5 & 44.75 & 1 & 64.75 & 27.8 & $\mathrm{~F}$ & 0.7 \\
\hline SUR 1 & 20 & 4.9 & 47.29 & 0 & 72.19 & 19.6 & $\mathrm{~F}$ & 0.8 \\
\hline PAI 1 & 15 & 6 & 62.11 & 0 & 83.11 & 11.4 & $\mathrm{~F}$ & 0.9 \\
\hline PAI 2 & 13 & 7 & 62.84 & 0 & 82.84 & 11.4 & $\mathrm{~F}$ & 0.9 \\
\hline TJI 1 & 24 & 6.2 & 49.39 & 0 & 79.59 & 10.5 & $\mathrm{~F}$ & 0.8 \\
\hline JEP 1 & 37 & 13 & 32.86 & 0 & 82.86 & 7.26 & $\mathrm{~F}$ & 0.9 \\
\hline JEP 2 & 27.3 & 5.9 & 45.99 & 0 & 79.19 & 9.77 & $\mathrm{~F}$ & 0.8 \\
\hline SUR 2 & 36 & 15 & 30.16 & 1.2 & 81.16 & 10.8 & $\mathrm{~F}$ & 0.9 \\
\hline TJI 2 & 41 & 13 & 29.24 & 0.74 & 83.24 & 7.86 & $\mathrm{~F}$ & 0.9 \\
\hline PAI 3 & 41.5 & 18 & 20.57 & 0.5 & 80.07 & 14.6 & $\mathrm{~F}$ & 0.9 \\
\hline OPC & 5 & 0 & 7.32 & 1.8 & 12.32 & 83.26 & - & - \\
\hline
\end{tabular}

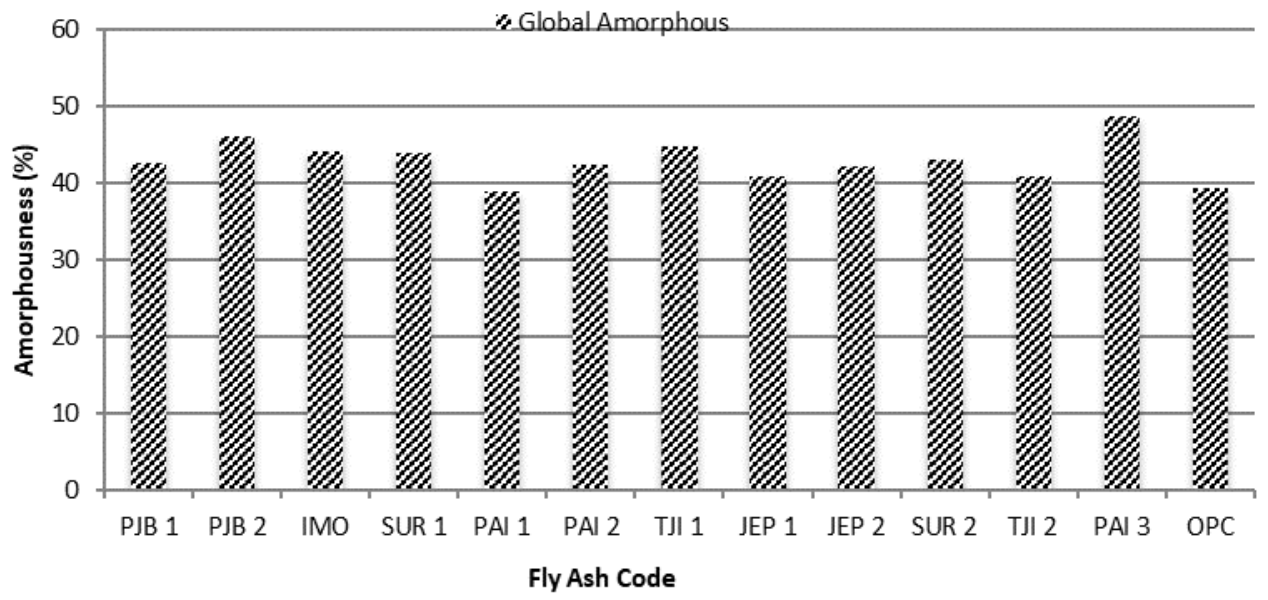

Fig. 1 Amorphous percentage of fly ash

2) Percentage Amorphous of Fly Ash: The percentage amorphous of fly ash is displayed in Fig. 1. From the figure, it is shown that almost all of the fly ash has the percentage of amorphous content more than $40 \%$.

\section{B. Approach Method}

There were 6 approach methods shown in below.

1) Method 1: The weight of fly ash was $20 \%$ by weight of the cementitious material, without sieving condition of fly ash. The form of specimens was mortar. Immediately after casting, the specimens were cured with immersion treatment. The compressive strength of specimens was determined after 7-day of the curing process.

2) Method 2: The weight of fly ash was $20 \%$ by weight of the cementitious material with no sieving condition of fly ash. The form of specimens was mortar. Immediately after casting, the specimens were cured with immersion treatment. The compressive strength of specimens was determined after 28-day of the curing process.
3) Method 3: The weight of fly ash was $20 \%$ by weight of the cementitious material with sieving condition of fly ash. The form of specimens was mortar. Immediately after casting, the specimens were cured with immersion treatment. The compressive strength of specimens was determined after 7-day of the curing process.

4) Method 4: The weight of fly ash was $10 \%$ by weight of the cementitious material, without sieving condition of fly ash. The form of specimens was mortar. Immediately after casting, the specimens were cured with moist treatment. The compressive strength of specimens was determined after 7day of the curing process.

5) Method 5: The weight of fly ash was $20 \%$ by weight of the cementitious material, with sieving condition of fly ash. The form of specimens was a paste, and the specimens were moist cured at 60 degrees Celcius for three hours. The compression tests of specimens were conducted after one day of casting.

6) Method 6: The weight of fly ash was $20 \%$ by weight of the cementitious material, without sieving condition of fly 
ash. The form of specimens was a paste, and the specimens were moist cured at 60 degrees Celcius for three hours. The compression tests of specimens were conducted after one day of casting.

\section{RESULTS AND DISCUSSION}

\section{A. The Compressive Strength Results}

The correlation of specific gravity, compressive strength, and index for each method are summarized in Table 2 and depicted in Fig. 2.

The numeral on the index column represents the compressive strength ratio of each mixture to the compressive strength of mixture with the paste of $100 \%$ OPC. The majority of the results as seen in Fig. 2 indicates that the Method 5 has the highest index, which was the method used steam curing high temperature and sieving condition of fly ash. It was due to differences in specimens curing temperature, and the difference in the level of material fineness will accelerate the cement hydration process, [3]. Moreover, enhancement the material fineness even increases the compressive strength of the specimen [4]. The same as Method 5 and 6, the difference is at the level of fineness, fly ash on the method of 5 has a higher fineness level than that of the method 6. Karim et al [5] said that fineness of ground disposed of fly ash plays a crucial role in the compressive strength of mortar.

TABLE II

SPECIFIC GRAVITY, COMPRESSIVE STRENGTH AND INDEX FOR EACH METHOD

\begin{tabular}{|c|c|c|c|c|c|c|c|c|c|c|c|c|c|}
\hline \multirow[b]{2}{*}{ CODE } & \multirow{2}{*}{$\begin{array}{l}\text { SPESIFIC } \\
\text { GRAVITY }\end{array}$} & \multicolumn{2}{|c|}{ Method I } & \multicolumn{2}{|c|}{ Method II } & \multicolumn{2}{|c|}{ Method III } & \multicolumn{2}{|c|}{ Method IV } & \multicolumn{2}{|c|}{ Method V } & \multicolumn{2}{|c|}{ Method VI } \\
\hline & & $f c^{\prime}(1)$ & Index & $\begin{array}{l}\mathbf{f c}^{\prime} \\
(\mathbf{2})\end{array}$ & Index & fc' (3) & Index & $\begin{array}{l}f^{\prime} \\
(4)\end{array}$ & Index & $\begin{array}{l}f^{\prime} \\
(5)\end{array}$ & Index & $\begin{array}{l}F^{\prime} \\
(6)\end{array}$ & Index \\
\hline PJB 1 & 2.38 & 21.6 & 0.79 & 26.6 & 0.74 & 29.60 & 1.08 & 32.5 & 1.38 & 28.0 & 1.72 & 26.5 & 1.63 \\
\hline PJB 2 & 2.5 & 26.3 & 0.96 & 26.3 & 0.73 & 36.90 & 1.347 & 33.0 & 1.40 & 34.1 & 2.09 & 14.3 & 0.88 \\
\hline IMO & 2.78 & 29.5 & 1.08 & 34.3 & 0.95 & 33.00 & 1.204 & 33.7 & 1.43 & 32.3 & 1.98 & 19.6 & 1.20 \\
\hline SUR 1 & 2.67 & 33.1 & 1.21 & 33.1 & 0.92 & 39.10 & 1.427 & 20.0 & 0.85 & 40.3 & 2.47 & 16.3 & 1.00 \\
\hline PAI 1 & 2.78 & 30.8 & 1.12 & 35.5 & 0.99 & 33.00 & 1.204 & 22.8 & 0.96 & 32.6 & 2.00 & 18.3 & 1.13 \\
\hline PAI 2 & 2.78 & 30.6 & 1.11 & 35.2 & 0.98 & 35.50 & 1.296 & 23.6 & 1.00 & 33.5 & 2.06 & 27.5 & 1.69 \\
\hline TJI 1 & 2.5 & 23.2 & 0.85 & 45.9 & 1.28 & 37.00 & 1.35 & 25.1 & 1.07 & 36.4 & 2.23 & 14.8 & 0.91 \\
\hline JEP 1 & 2.08 & 23.4 & 0.85 & 35.6 & 0.99 & 24.90 & 0.909 & 27.6 & 1.17 & 19.6 & 1.20 & 11.4 & 0.70 \\
\hline JEP 2 & 2.38 & 24.6 & 0.90 & 32.1 & 0.89 & 26.00 & 0.949 & 27.0 & 1.14 & 18.3 & 1.13 & 13.0 & 0.80 \\
\hline SUR 2 & 2.43 & 27.5 & 1.00 & 48.0 & 1.34 & 30.50 & 1.113 & 22.4 & 0.95 & 19.9 & 1.22 & 13.8 & 0.84 \\
\hline TJI 2 & 2.38 & 23.9 & 0.87 & 29.1 & 0.81 & 26.00 & 0.949 & 23.9 & 1.01 & 15.5 & 0.95 & 9.7 & 0.59 \\
\hline PAI 3 & 2.27 & 33.0 & 1.20 & 38.4 & 1.07 & 34.00 & 1.241 & 22.8 & 0.96 & 21.4 & 1.31 & 13.8 & 0.84 \\
\hline OPC & 3.1 & 27.4 & 1.00 & 35.9 & 1.00 & 27.40 & 1 & 23.6 & 1.00 & 16.3 & 1.00 & 16.3 & 1.00 \\
\hline
\end{tabular}

Index of Fly Ash

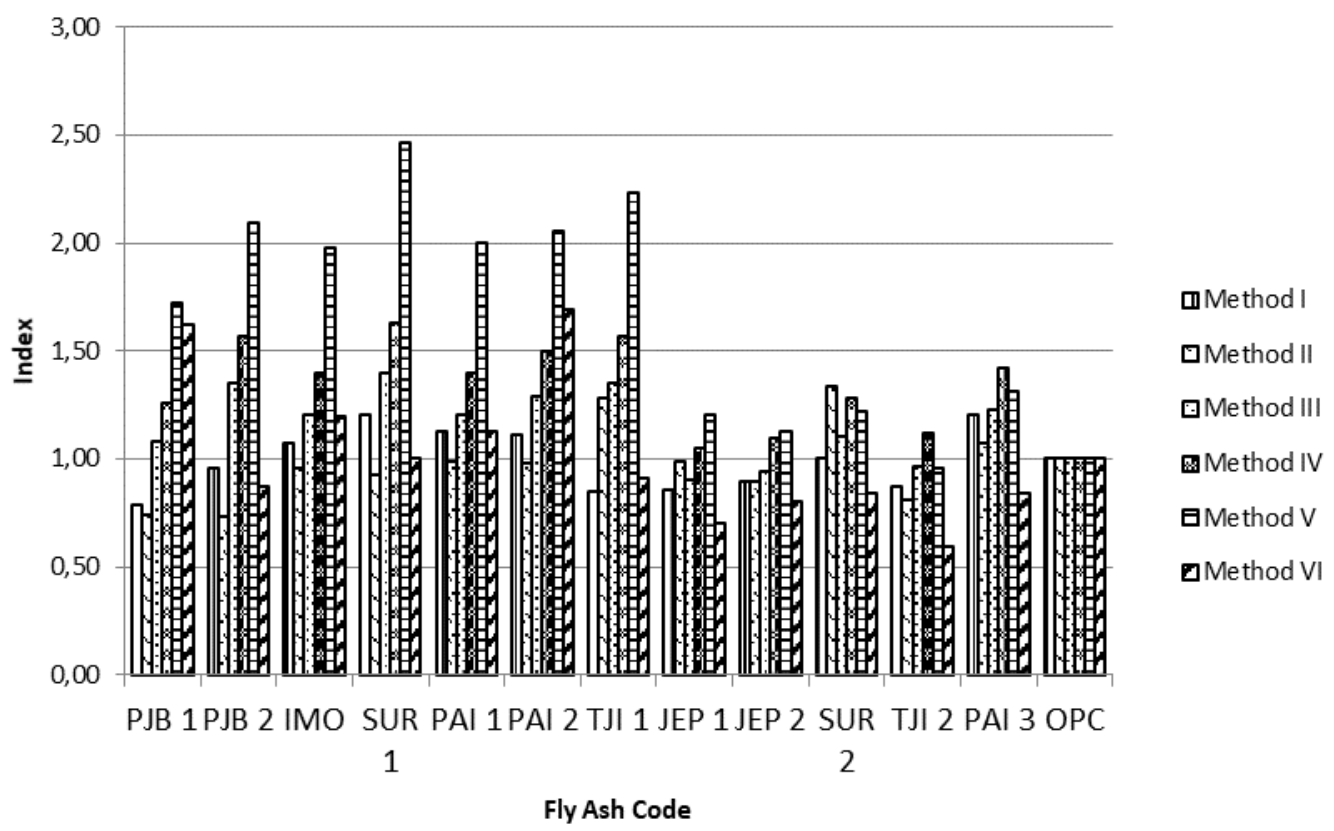

Fig. 2 Compressive strength index of each method 
TABLE III

CARBON CONTENT OF FLY ASH

\begin{tabular}{|c|c|c|c|}
\hline No. & $\begin{array}{c}\text { Carbon } \\
\text { Content }(\boldsymbol{\%})\end{array}$ & Carbon Content Index & Strength Activity Index \\
\hline PJB 1 & 13.4 & 1.34 & 1.20 \\
\hline PJB 2 & 11 & 1.10 & 1.26 \\
\hline IMO & 3.2 & 0.32 & 1.30 \\
\hline SUR 1 & 5.1 & 0.51 & 1.44 \\
\hline PAI 1 & 3 & 0.30 & 1.31 \\
\hline PAI 2 & 3 & 0.30 & 1.44 \\
\hline TJI 1 & 7.2 & 0.72 & 1.36 \\
\hline JEP 1 & 4.3 & 0.43 & 0.95 \\
\hline JEP 2 & 3.9 & 0.39 & 0.96 \\
\hline SUR 2 & 4.9 & 0.49 & 1.13 \\
\hline TJI 2 & 7.1 & 0.71 & 0.89 \\
\hline PAI 3 & 3 & 0.30 & 1.18 \\
\hline
\end{tabular}

TABLE IV

Mineral Content on Fly Ash

\begin{tabular}{|c|c|c|c|c|c|}
\hline \multirow[b]{2}{*}{ CODE } & \multicolumn{3}{|c|}{ Mineral } & \multirow{2}{*}{$\begin{array}{c}\text { Global } \\
\begin{array}{c}\text { Amorphous } \\
\text { (GA) }\end{array} \\
\end{array}$} & \multirow{2}{*}{$\frac{\text { Index }}{\text { GA }}$} \\
\hline & $\begin{array}{l}\text { Quartz } \\
\left(\mathrm{SiO}_{2}\right)\end{array}$ & Mullite $\left(\mathrm{Al}_{\mathbf{6}} \mathbf{S i}_{12} \mathbf{O}_{3}\right)$ & $\begin{array}{c}\text { Hematite } \\
\left(\mathrm{Fe}_{2} \mathrm{O}_{3}\right)\end{array}$ & & \\
\hline PJB 1 & 16.4 & 31.6 & 9.4 & 42.6 & 1.084 \\
\hline PJB 2 & 26.1 & 6.4 & 21.4 & 46.1 & 1.173 \\
\hline IMO & 30.5 & 15.3 & 10.1 & 44.1 & 1.122 \\
\hline SUR 1 & 13.7 & 29.5 & 12.9 & 43.9 & 1.117 \\
\hline PAI 1 & 13.7 & 30.3 & 17 & 39 & 0.992 \\
\hline PAI 2 & 9.9 & 12.9 & 34.6 & 42.5 & 1.081 \\
\hline TJI 1 & 14.4 & 31.6 & 9.2 & 44.8 & 1.140 \\
\hline JEP 1 & 15.5 & 29 & 14.5 & 41 & 1.043 \\
\hline JEP 2 & 25.3 & 23.1 & 9.3 & 42.3 & 1.076 \\
\hline SUR 2 & 27.7 & 26 & 12.3 & 43 & 1.094 \\
\hline TJI 2 & 18.1 & 28.9 & 11.9 & 41 & 1.043 \\
\hline PAI 3 & 8.9 & 23.3 & 19 & 48.8 & 1.242 \\
\hline OPC & - & - & - & 39.3 & 1.000 \\
\hline
\end{tabular}

\section{B. Influence of Carbon Content in Fly Ash}

The influence of carbon content in fly ash to the compressive strength is shown in Table 3. The carbon content was calculated based on the weight of fly ash retained on the 200 mesh. Furthermore, the determination of carbon index according to ASTM standard, for carbon content $5 \%$ given index 0.5 , while the compressive strength index was derived from the average value of the compressive strength index per each method. From the data Table 3. it can be mentioned that it is not easy to find the correlation between carbon content and compressive strength. McCarter et al. [6] search for pozzolan reactivity of four kinds of material that were metakaolin, micro-silica, PFA (pulverized fuel ashes) and GGBS (ground granulated blast furnace slag). GGBS which has the highest carbon content has the lowest pozzolanic reactivity, but from the other three materials, the relationship between carbon content and pozzolan reactivity were not comparable. Hardjito [7] stated that fly ash with low carbon content provides high compressive strength to geopolymer concrete. Malvar [8] revealed that high levels of carbon content increase expansion. However, the last two authors did not mention how the direct relation between carbon content in fly ash and compressive strength was. The reality is not simple to find a direct connection between carbon content in fly ash and compressive strength of mortar.

\section{Mineral Content in Fly Ash}

The minerals content of fly ash is shown in Table 4. The majority of minerals contained in fly ash were quartz ( $\mathrm{SiO} 2)$, mullite (Al6Si12O3) and hematite (Fe2O3). Similar to Fernandez's [10] research that the majority of minerals are quartz, mullite, hematite. The numeral on the index global amorphous (GA) column represents the number of the ratio 
Method 1 and Method 3

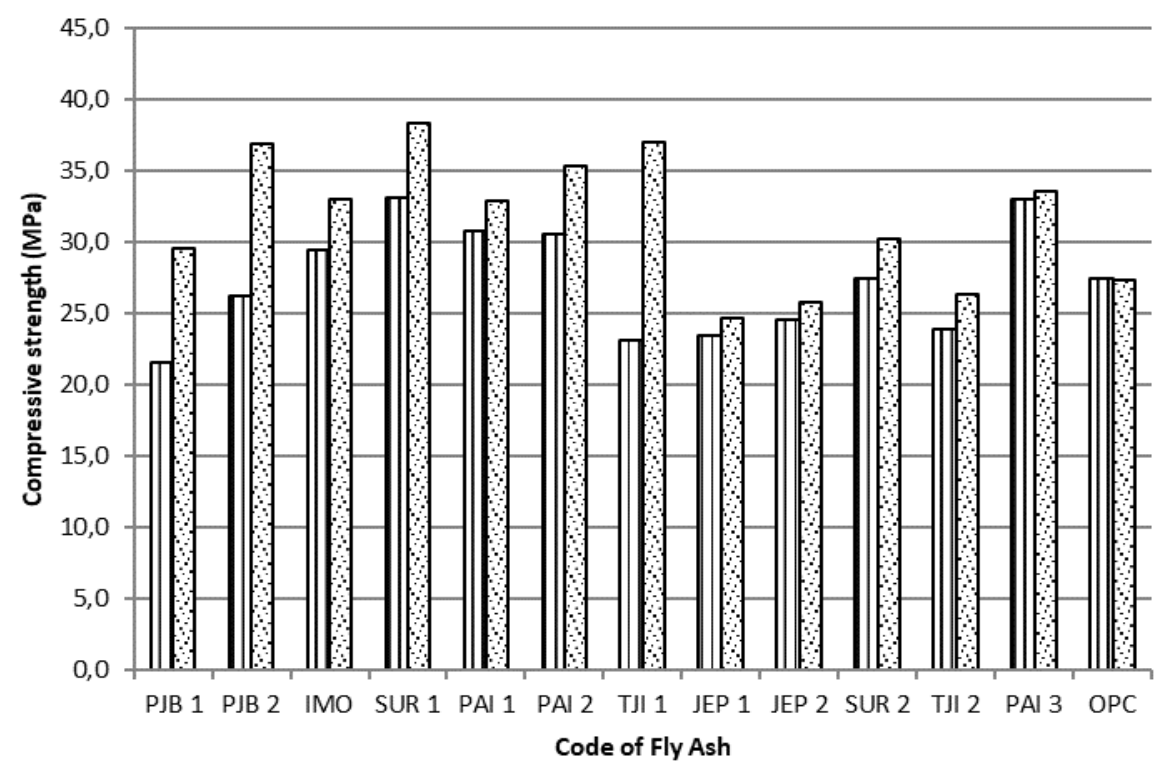

mMethod I

GMethod III

Fig. 3 The compressive strength comparison of Method 1 and Method 3

Method 5 and Method 6

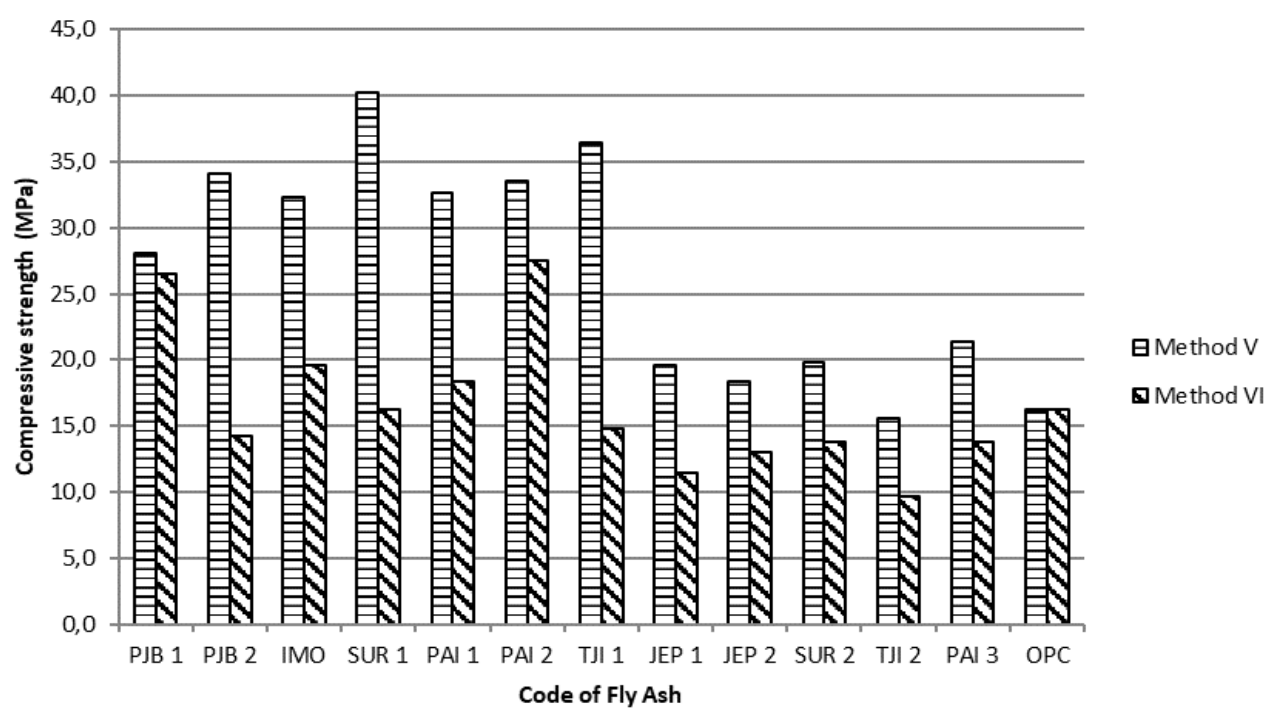

Fig. 4 The compressive strength comparison of Method 5 and Method 6

among GA percentage of each fly ash to the GA of OPC (Ordinary Portland Cement), by setting index 1 in the GA index for OPC. Table 4 indicates that mineral content in fly ash is uncertain.

In the case of Tables 3 and 4, it appears that fly ash containing the highest percentage of global amorphous did not indicate the highest compressive strength index. This is also in accordance with the research of Skavarla [9] which resulted that the chemical composition not being used to predict compressive strength. Fernandez [10] and Nurwidayati [10] stated that oxides do not form a part of the main reaction products, and consequently, they do not significantly contribute to the mechanical strength development. As shown in Table 4 there is no relation between the mineral content and compressive strength.

\section{Different Results of Methods 1 and 3}

The different results of compressive strength of Methods 1 and 3 are displayed in Fig. 3. The figure emphasizes that the increase of material fineness will increase the compressive strength. In Fig. 3 although the same level of fly ash fineness but the increasing of percentage in the compressive strength were not equal, this argument applies to Fig. 4 as well. The images confirmed that the compressive strength and mineral content were not related directly too. Fernandez [11], [12] stated that from the chemical point of view the most important factor is the reactive silica content. 
Silica is the main constituent of the structural skeleton of the reaction product formed in the alkaline activation of the ashes.

\section{E. Different Results of Methods 5 and 6}

The results of compressive strength Methods 5 and 6 are displayed in Fig. 4. The different method 5 and 6 were the degree of fly ash fineness and the duration of the curing process. The argument of the increase in fly ash fineness is similar to an explanation in Fig. 3. When comparing Fig. 3 and 4 , the difference is the curing method and the age of the compressive strength test. In Fig. 4 the specimens were cured at high temperature, and the compressive strength tests were performed at the age of 1 day, while in Fig. 3 the specimens were cured at ambient temperature, and compressive strength tests carried out at the age of 7 days. Meanwhile, the compression rate is not much different. The maximum compressive strength of Method 3 in Fig. 3 is about $38.5 \mathrm{MPa}$, while on Method 5 in Fig. 4 is about 40 MPa. In terms of time, in Fig. 4 the compressive strength tests were done at the age of 1-day, while in Fig. 3, the compressive strength tests performed at the age of 7-day.

\section{F. General Discussion.}

It is already known that there are numbers of variations of fly ash in the field, including the physical properties and chemical content. In the current situation, the use of fly ash is very significant, either as a normal concrete mix or as the basic material of geopolymer concrete [13]. However, so far, a direct relationship between the physical and chemical properties of fly ash to the compressive strength of concrete is not easy to predict. As well as the existing results of this study, it is relatively not simple to relate the relationship between the total amorphous, the mineral content, the oxide content to the compressive strength directly. Moreover, to analyze the oxide content with XRF (X-Ray Fluorescence) and to analyze the mineral content by XRD (X-Ray Diffractometer) requires a budget that is costly. For that reason, it needs to find another alternative method to connect fly ash with compressive strength directly.

The main purpose of the study was to determine the relationship between fly ash to the compressive strength of the mortar test specimen. From the description of the study results show the most appropriate is method 5, relatively fast and cheap enough.

\section{CONCLUSION}

Results in this paper have shown that it is not easy to find a direct relationship between the total amorphous, the mineral content, the oxide content to the compressive strength of mortar.

To characterize fly ash to the compressive strength of the mortar, Method 5 is found to be relatively cheap and fast whereby the method employs the use of paste mixture with the weight of fly ash is $20 \%$ by weight of the cementitious material, with sieving condition of fly ash. A special condition in this method is moist curing at a temperature of 60 degrees Celcius for three hours and compressive strength test conducted at one day after casting.

\section{ACKNOWLEDGMENTS}

The authors gratefully wish to acknowledge the Ministry of Research, Technology, and Higher Education of the Republic of Indonesia for the financial support throughout the course of this research.

\section{REFERENCES}

[1] Januarti Jaya Ekaputri, Triwulan, Khorin Agus Priadana, Tri Eddy Susanto and Subaer Junaedi. "Physico-Chemical Characterization of Fly Ash" The 2013 World Congress On Advances in Structural Engineering and Mechanics (ASEM 13) Jeju, Korea, September 812,2013

[2] ASTM C618-03, 2003, "Standard Specification for Coal Fly Ash and Raw or Calcined Natural Pozzolan for Use as a Mineral Admixture in Concrete", Annual Book of ASTM Standard.

[3] Triwulan, Luvi Yusepa Dwijayanti, Januarti Jaya Ekaputri ,Ridho Bayuaji, "Lightweight Geopolymer Binder With Abaca Fiber In Different Curing". Materials Science Forum Issn: 1662-9752, Vol. 841, Pp 140-147.2016.

[4] Hongzhu Quan "The Effects of Change in Fineness of Fly Ash On Air-Entraining Concrete", The Open Civil Engineering Journal, 2011, 5, 124-131,2011.

[5] M. R. Karim, M. F. M. Zain, M. Jamil, F. C. Lai and M. N. Islam "Strength Development of Mortar and Concrete Containing Fly Ash: A Review" International Journal of The Physical Sciences Vol. 6(17), Pp. 4137-4153. 2011.

[6] W. J. Mccarter and D. Tran "Monitoring Pozzolanic Activity by Direct Activation with Calcium Hydroxide" Construction and Building Materials, Vol. 10, No. 3, Pp. 179-184,1996.

[7] D. Hardjito and B. V. Rangan "Development and Properties of LowCalcium Fly Ash-Based Geopolymer Concrete "Research Report Gc 1 Faculty of Engineering Curtin University of Technology, Perth, Australia, 2005.

[8] L. J. Malvar 1, L. R. Lenke 2 "Efficiency of Fly Ash in Mitigating Alkali Silica Reaction Based on Chemical Composition "Aci Materials Journal, Vol. 103, No. 5, Pp. 319-326, 2006.

[9] Skavarla, J., Sisol, M., Botula, J., Kolesarova., M., Dan Krinicka, I "The Potential Use of Fly Ash with a High Content of Unburned Carbon in Geopolimers." Science Direct. Acta Geodyn. Geomater., Vol. 8, No. 2 (162), 123-132, 2011.

[10] Nurwidayati, R., J.J. Ekaputri, M. Bahrul Ulum, Triwulan and P. Suprobo, "Characterization of Fly Ash on Geopolymer Paste", Materials Science Forum Vol. 841, 118-125, 2016.

[11] A. Fernandez -Jimenez, A.Palomo "Characterization Of Fly Ashes. Potential Reactivity as Alkaline Cements "Elsevier Fuel 82 (2003) 2259-2265, 2003.

[12] Ekaputri Januarti Jaya ,Ulum Muhammad Bahrul, Triwulan ,Ridho Bayuaji , Susanto Tri Eddy and Mohd Mustafa Al Bakri Abdullah . "A Comprehensive Characterization and Determination of Fly Ashes In Indonesia using Different Methods" Applied Mechanics and Materials Vols. 754-755 pp 320-325,2016.

[13] Triwulan, Prasma Wigestika and Januarti Jaya Ekaputr, "Addition Of Superplasticizer On Geopolymer Concrete " ARPN Journal of Engineering and Applied Sciences, Vol. 11, No. 24,14456-14462, 2016. 